\title{
Psychological Determinants of Graduate Employability: A Comparative Study of Business and Agriculture Students Across Pakistan
}

\author{
Haroon Bakari ${ }^{1}$, Imamuddin Khoso ${ }^{2}$
}

\begin{abstract}
Determinants of graduate employability is a point of major concern for academician, practitioners, and Governments across the globe as more than 80 percent ( 74 percent in Pakistan) university graduates intend to choose employment as a career right after completion of their studies. In this regard, the role of psychological resources like the Psychological Capital (PsyCap) in academic settings has been regarded as relevant and important contributor towards graduates' outcomes but this phenomenon has received very little attention of empirical studies. This paper aims to investigate the level of PsyCap and self-perceived employability (SEP) of business and agriculture students and investigate the link between PsyCap and SEP. The data were collected from 339 graduates enrolled in bachelor, masters and $\mathrm{PhD}$ degree programs of agriculture and business departments of three universities of Islamabad, Punjab and Sindh. Means were compared using independent sample t-test and ANOVA, whereas, for hypothesis testing, structural equation modelling was applied using AMOS. Results indicate that no significant difference was found between business and agriculture students with regard to psychological capital and self-perceived employability as these are equally important for business and agriculture graduates. However, the graduates differed on the basis of the degree program they were enrolled in such that students of the master's degree program scored higher on the means of PsyCap and SEP. Structural equation modeling (SEM) indicated that hope, optimism, and self-efficacy were positively and significantly related to SEP whereas, resilience was not found significant with SEP. Main implication for this study is the need for the development of students' PsyCap during academic life to enhance employability perceptions of graduates.
\end{abstract}

Keywords: Graduate employability; psychological capital; agriculture graduates; business graduates; Pakistan.

\footnotetext{
1 Lecturer, MBBS Campus Dadu, University of Sindh. Email: haroon.bakari@usindh.edu.pk

2 Professor, Institute of Business Administration, University of Sindh, Jamshoro, Email: imam.khoso@ usindh.edu.pk
}

\begin{tabular}{lll} 
ARTICLE HISTORY \\
\hline 2 Aug, 2017 Submission Received & 16 Aug, 2017 & First Review \\
\hline 22 Aug, 2017 Revised Version Received & 3 Oct, 2017 & Second Review \\
\hline 8 Oct, 2017 Revised Version Received & 10 Nov, 2017 & Accepted
\end{tabular}




\section{Introduction}

Human capital is considered to be an important asset for the development of the organizations and serves as a competitive advantage. The universities are the major source of development of high quality human capital through extended access to higher education (Bakari, Hunjra, \& Saman, 2017; Qenani, MacDougall, \& Sexton, 2014) and prepare the graduates to meet the challenges faced by the industry (Martin, Milne-Home, Barrett, Spalding, \& Jones, 2000). Business schools are assigned top responsibility to build up human capital through equipping the graduates with requisite skills, knowledge and, competencies for their ultimate success in workplace and serve as an agent of competitive advantage (Luthans, Luthans, \& Jensen, 2012). The Pakistani economy though observing improvement in industrial development, still heavily depends upon the agriculture. Therefore, agriculture education has been of great interest of the Pakistani youth for employment as well as entrepreneurial ventures. To fulfill the rising demand of agricultural employment, agricultural education programs needs to be dynamic in nature to cater for the emerging challenges posed by advances in technology in foods, agriculture extension, fertilizers, water technologies and natural resources industry (Zarafshani, Knobloch, \& Aghahi, 2008).

This decade has witnessed a rising interest of scholars and academicians in measuring employability perception of graduates of higher education institutes to guide the policy makers to make graduates' transition from education to work meaningful. A recent report on entrepreneurial intentions of graduates across the 50 countries reveals that about 80.3 percent ( 74 percent in Pakistan) university graduates intend to choose employment as a career right after completion of their studies (Samo \& Mahar, 2016; Sieger, Fueglistaller, \& Zellweger, 2016). A recent article by Luthans, Luthans, and Palmer (2016) employing 95 undergraduates of an American business school tested the role of students' psychological resources, that is, psychological capital (PsyCap; hope, self-efficacy, resilience, and optimism) in enhancement of students' grades measured through grade point average (GPA). The results shown a positive link of academic PsyCap with GPA. Authors suggested replication of study in other contexts with larger sample and test the role PsyCap may have in the development of SEP.

The purpose of this study is twofold: firstly, to measure the level of PsyCap and SEP of business and agriculture students and compare mean scores obtained by both groups. Secondly, to test the impact of PsyCap on SEP through SEM. In the first section of this article, we will compare means of PsyCap and SEP of business and agriculture students and in the next section we will propose and test a conceptual model that measures the impact of PsyCap on self-perceived employability. 


\section{Literature Review}

\subsection{Psychological capital}

Psychological capital, conceived by Luthans and colleagues, is rooted in the positive organizational behavior (POB). Psychological capital "PsyCap" is defined as: An individual's positive psychological state of development that is characterized by (1) having confidence (efficacy) to take on and put in the necessary effort to succeed at challenging tasks; (2) making a positive attribution (optimism) about succeeding now and in the future; (3) persevering towards goals and, when necessary, redirecting paths to goals (hope) in order to succeed; and (4) when beset by problems and adversity, sustaining and bouncing back and even beyond (resiliency) to attain success. (Luthans, Youssef, \& Avolio, 2015).

Hope, having roots in goal-setting theory is defined as a positive motivational state of mind through which a person sets the goals and plans to achieve those goals (Snyder, Irving, \& Anderson, 1991). The hope has two components: first is goal-directed energy (agency) and the second is planning to achieve it (pathways). Optimism on the other hand refers to 'generalized expectancy that good things will happen' (Scheier \& Carver, 1985). It is an expectancy that in the most situations he / she will attain the objectives and any negativity in this regard is temporary (Fibel \& Hale, 1978; Seligman, 1998). Self-efficacy is one's confidence in his / her abilities to meet some challenges, mobilize all available resources, capabilities and energies in a given context to achieve the goal (Bandura, 1986; Stajkovic \& Luthans, 1998). Resilience is an ability of a person to regain his strength after failure or even in the event of high success. It means nothing can stop a person from progressing either it may be a failure or achievement of goal. Resilience is defined as "the capacity to rebound or bounce back from adversity, conflict, failure, or even positive events, progress, and increased responsibility" (Luthans, 2002, p. 702).

Research suggests that the psychological capital is positively and significantly related to an organizationally desirable job outcomes and behaviours such as Job satisfaction and organizational commitment and negatively related to undesirable organizational outcomes such as turnover intention, cynicism and deviance (Avey, Reichard, Luthans, \& Mhatre, 2011; Youssef \& Luthans, 2012). PsyCap has been proved to be a second-order factor comprised of four inter-related latent constructs of hope, optimism, resilience and efficacy (Dawkins, Martin, Scott, \& Sanderson, 2013). All these four constructs form a valid second-order measure and their relationship is grounded in theory and verified conceptually and empirically (Avey et al., 2011).

\subsection{Self-perceived employability}

Graduate employability though has witnessed a rising interest of scholars recently, 
yet lacks universally accepted definitions with empirical support (Pool \& Qualter, 2013). A very important definition offered by Yorke (2006) is widely used by scholars, that is, '[a] set of achievements-skills, understandings, and personal attributes-that makes graduates more likely to gain employment and be successful in their chosen occupations, which benefits themselves, the workforce, the community and the economy' (p. 8). Some other authors also emphasized on the graduate attributes necessary for the inclusion of graduates into the workforce. Such attributes consist of sets of knowledge, skills, qualities, understandings, and personal attributes that students develop during their stay at educational institutes. These help students attain, secure and retain employment, leading them to remain satisfied and contribute towards society (Bowden, Hart, King, Trigwell, \& Watts, 2000; Pool \& Sewell, 2007).

\subsection{Impact of psychological capital on self-perceived employability}

PsyCap has been tested mainly in employment contexts, however recently more research has emerged in measurement and development of PsyCap in academic contexts (Luthans et al., 2016). Riolli, Savicki, and Richards (2012) have found psychological capital as a 'buffer' to students' stress. Analyzing responses from 141 business graduates of an American University, authors suggested that PsyCap is a tool to strengthen mental capability of students to cope with the stress caused due to variety of reasons and it is also a source of students' well-being. Another study by Luthans et al. (2012) also found positive link of PsyCap with students' academic performance. Luthans et al. (2016) in a study of 323 Midwestern business students found positive link of PsyCap with students' engagement. Authors also suggested to develop interventions to strengthen PsyCap in students as well as to check the potential role of PsyCap in enhancement of graduate employability.

Pool (2017) developed a CareerEDGE model in which he argued that for the graduates to be employable and successful in their careers ahead, it is necessary that they may be exposed to internships and work experience, relevant degree qualification of relevant field and some generic skills. Besides this, an important contributor that author found is emotional intelligence, self-efficacy, self-esteem and self-confidence. Author argues that these psychological resources are important contributors to self-perceived employability and supersede traditional conceptualization that emphasize more on a set of generic skills. They stressed the need to empirically test the impact of such psychological resources on graduate employability. This study may not replicate and empirically test full CareerEDGE model, rather uses psychological capital which also incorporates elements of this model and tests its impact on self-perceived employability. Thus, this study infers the following hypotheses:

Hypothesis 1: Students' Optimism will be positively related to their self-perceived employability. 
Hypothesis 2: Students' Resilience will be positively related to their self-perceived employability.

Hypothesis 3: Students' Self-efficacy will be positively related to their self-perceived employability.

Hypothesis 4: Students' Hope will be positively related to their self - perceived employability.

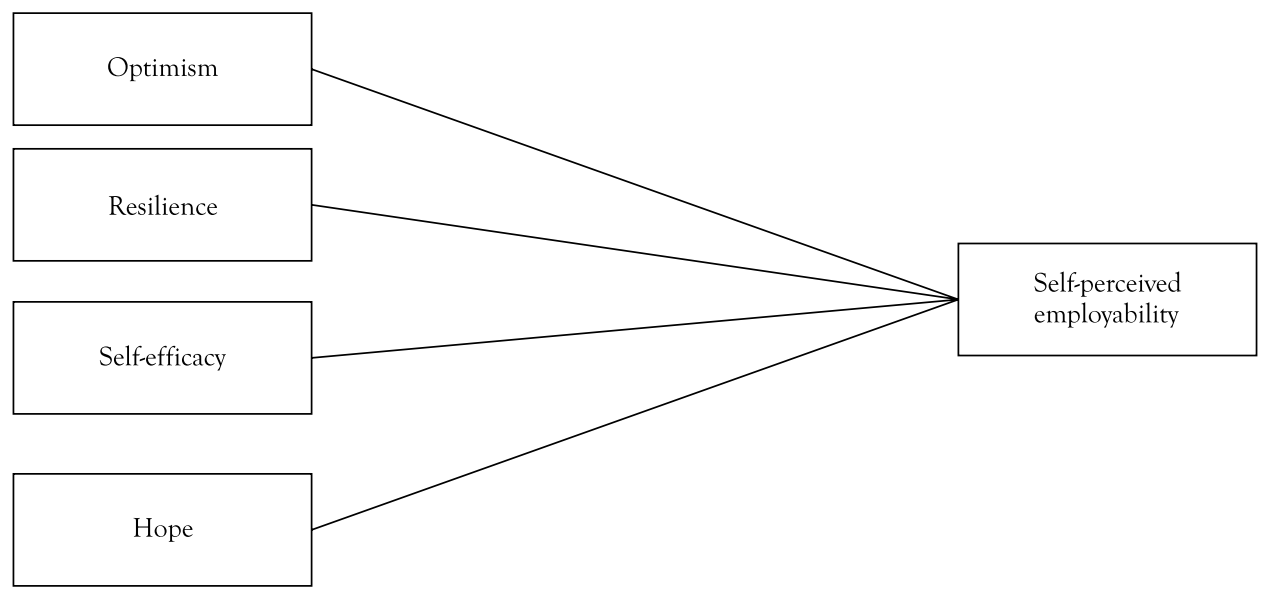

Figure 1: Conceptual Framework

\section{Methodology}

Following positivist philosophy, this study applied deductive approach and collected cross-sectional data from the business and agriculture students through structured survey using the convenience sampling method. Data were collected from bachelors, masters and doctoral students from management sciences department of a military university (Mil Uni), an agriculture university (Agri Uni) and a general university (Gen Uni) based in Islamabad, Rawalpindi and Jamshoro respectively. Total 500 questionnaires were distributed both online and manually, and out of them, 339 responses were received yielding response rate of $68 \%$. The responses on study variables were on a five-point Likert scale where 1 represented strongly disagree and 5 represented strongly agree.

\subsection{Measures}

Psychological capital (PsyCap) was measured using a 24-item scale of PsyCap developed and validated by Luthans, Avolio, Avey, and Norman (2007) ${ }^{3}$. This scale 3 Permission was sought for the use of the scales from the copyright owners through procedure envisaged at www.mindgarden.com. 
consists of four dimensions comprising six items each. As the sample included students with a minimum bachelor degree; therefore, an English version of the questionnaire was used. Sample items include 'I have a strong will to achieve my goals' (hope), 'I am always optimistic about my future' (optimism), 'I enjoy dealing with new and unusual events' (resilience), 'I enjoy a great deal of self-confidence' (Self-efficacy).

Second variable is self-perceived employability which refers to students' perception of themselves being employable based on their perception of the field of study, university, economy and self-belief. To measure self-perceived employability, a 16-item scale developed by Rothwell, Herbert, and Rothwell (2008) was used. Two sample items include: 'I am generally confident of success in job Interviews and selection events' and 'I can easily find out about opportunities in my chosen field'.

\section{Results}

This section elaborates the results and analysis strategy. In the first section, descriptive and inferential statistics are used to compare means and test the difference of means among various groups of data using independent sample t-test and analysis of variance (ANOVA) techniques. In second section, structural equation modeling is used to test hypothesis.

\subsection{Descriptive statistics}

This analysis is done in two sections. First section deals with the frequency distribution of data and descriptive statistics with regards to demographic variables. Second section presents the frequency tables and descriptive statistics of study variables.

Table 1: Gender-wise Frequency Distribution $(\mathrm{n}=339)$

\begin{tabular}{|c|c|c|}
\hline Gender & Number & Percent \\
\hline Male & 195 & $58 \%$ \\
\hline Female & 144 & $42 \%$ \\
\hline Total & 339 & $100(\%)$ \\
\hline
\end{tabular}

Source: Primary data based on this study

Table 1 divides the data in terms of male and female respondents. Former is higher in percentage than that of latter. Results reveal that 42 percent females (144 respondents) participated in this study, whereas, participation of male students was 58 percent (195 respondents). Ratio of female respondents is slightly less than their counter parts because females' enrolment is lesser than males, moreover, due to cultural limitations less follow ups were made to female respondents (Bakari, Hunjra, \& Niazi, 2017). 


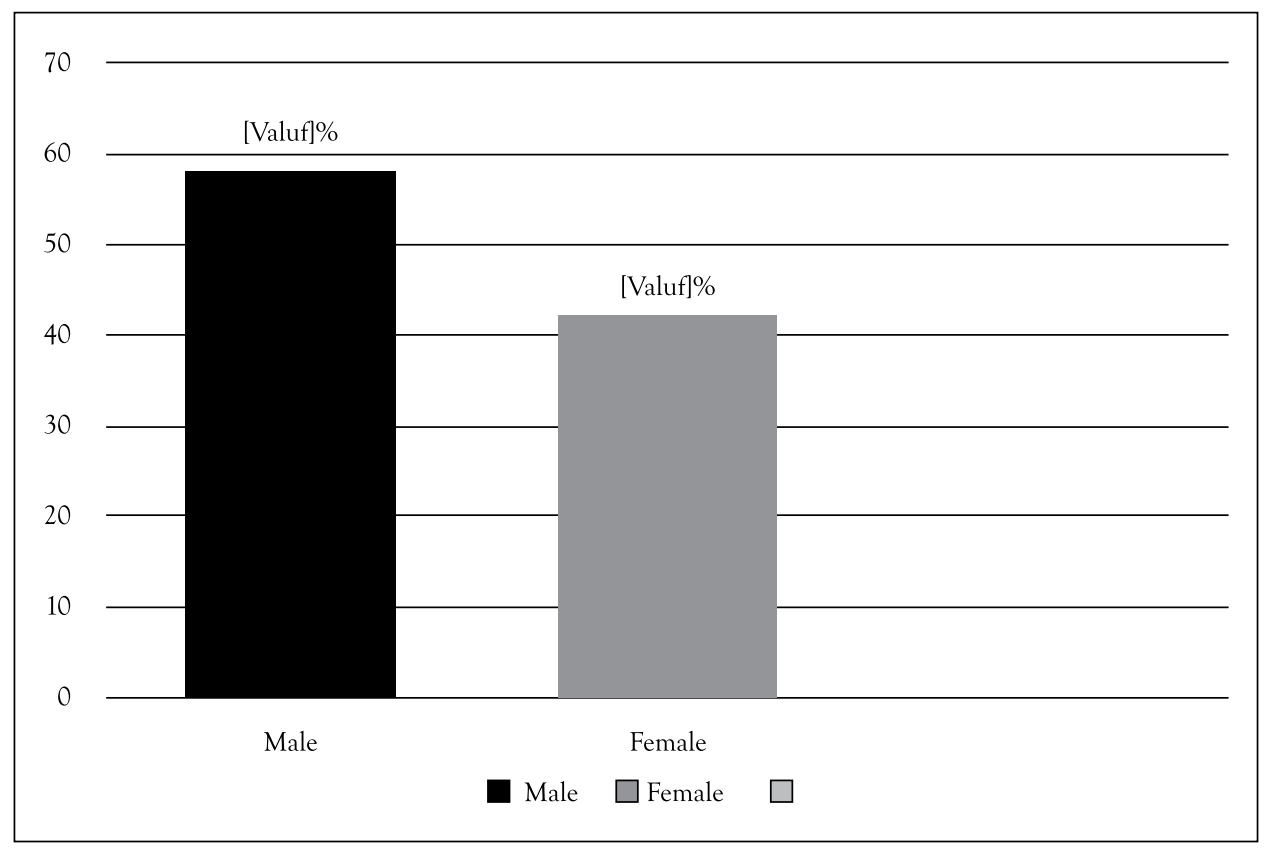

Figure 2: Gender-wise Distribution of Sample $(\mathrm{n}=339)$

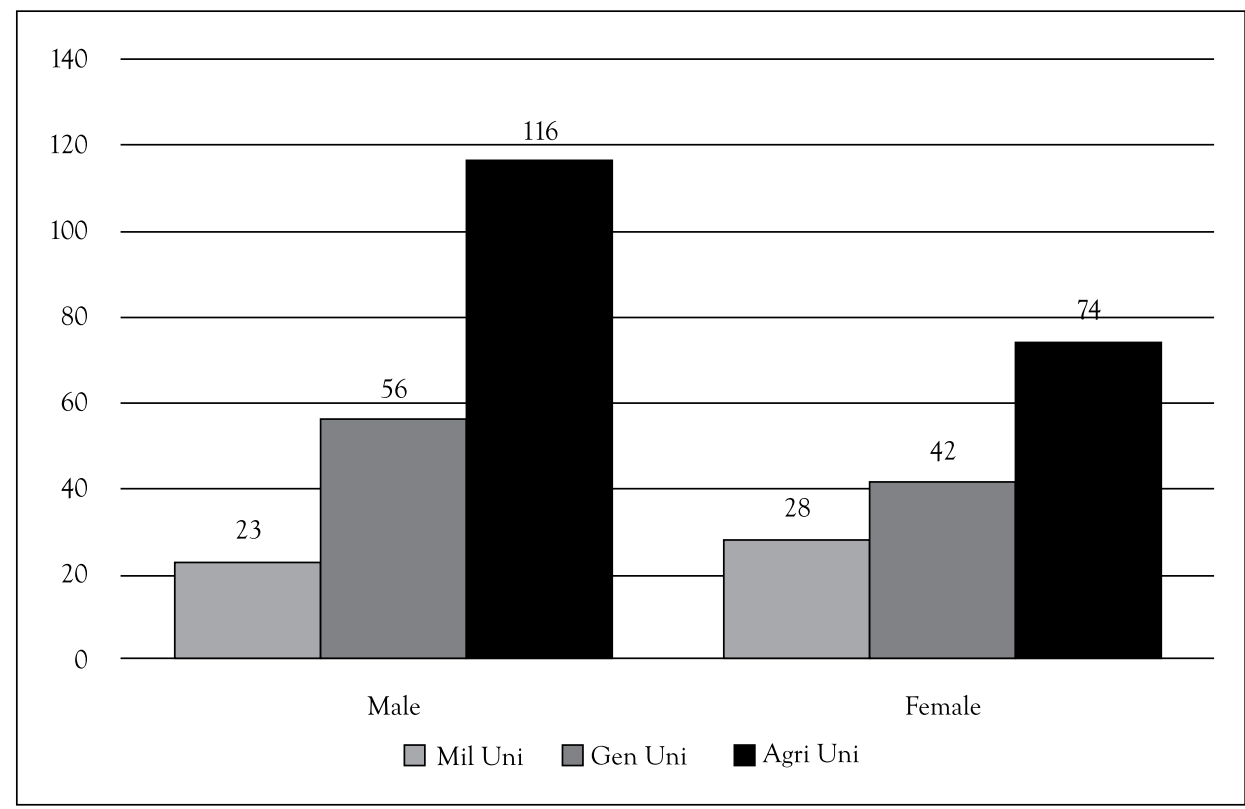

Figure 3: Institution-wise Distribution of Sample $(\mathrm{N}=339)$

Figure 3 summarizes the respondents from different universities. These universities are listed as per order they were contacted. The results indicate that 190 students belong to an agriculture university because the students from both groups, that is, the 
business and agriculture participated from this university. The number of students from the business department of a large general university and a military university was 98 and 51 respectively.

Table 2: Age-wise Frequency Distribution $(n=339)$

\begin{tabular}{|c|c|c|}
\hline Age group & Number & Percent (\%) \\
\hline less than 17 & 6 & 1.8 \\
\hline $18-25$ & 245 & 72.3 \\
\hline $26-30$ & 70 & 20.6 \\
\hline $31-35$ & 18 & 5.3 \\
\hline Above 35 & 0 & 0 \\
\hline Total & 339 & 100.0 \\
\hline
\end{tabular}

Source: Primary data based on this study

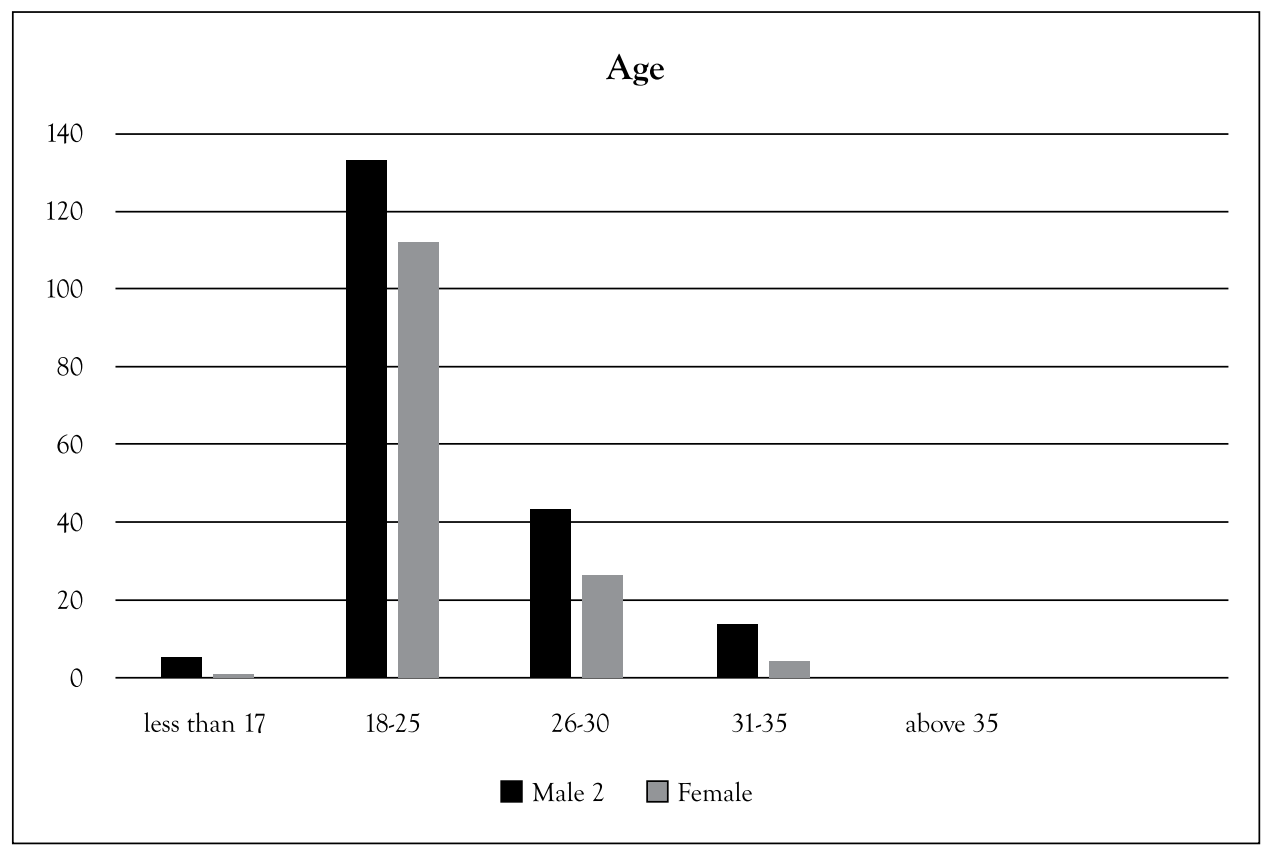

Figure 4: Age-wise Frequency Distribution $(\mathrm{n}=339)$

Table 2 shows the age distribution of the sample. Sample was overwhelmed by the youth of age bracket 18 to 25 years ( 245 respondents: 72.3 percent) followed by 70 students of 26 to 30 years age (28.7 percent), whereas, 18 respondents reported to be of the age of $31-35$ years (5.3 Percent). There was no any participant above age 35 . 
Table 3: Marital Status Wise Frequency Distribution $(\mathrm{n}=339)$

\begin{tabular}{|c|c|c|}
\hline Marital Status & Number & Percent (\%) \\
\hline Single & 310 & 91.4 \\
\hline Married & 29 & 8.6 \\
\hline Total & 339 & 100.0 \\
\hline
\end{tabular}

Source: Primary data based on this study

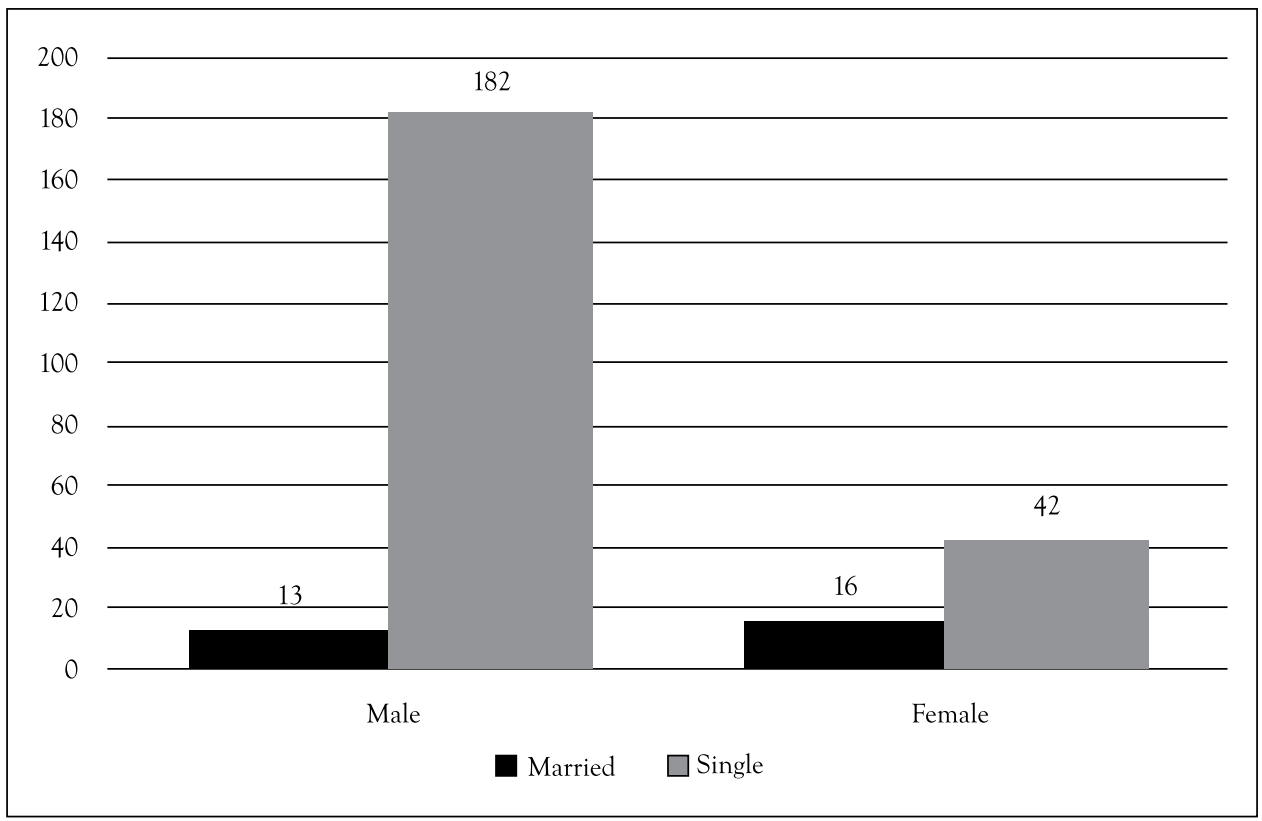

Figure 5: Marital Status Wise Frequency Distribution $(\mathrm{n}=339)$.

Table 3 demonstrates the marital status of the respondents. Results reveal that 91.4 percent were single or unmarried. Only 29 students reported that they were married at the time of data collection.

Table 4: Field of Study Wise Frequency Distribution

\begin{tabular}{|c|c|c|c|c|}
\hline & Male & Female & Total & Percent \\
\hline Business & 109 & 106 & 215 & 63.5 \\
\hline Agriculture & 68 & 32 & 100 & 29.5 \\
\hline Other & 18 & 6 & 24 & 7 \\
\hline Total & 195 & 144 & 339 & 100 \\
\hline
\end{tabular}

Source: Primary data based on this study 


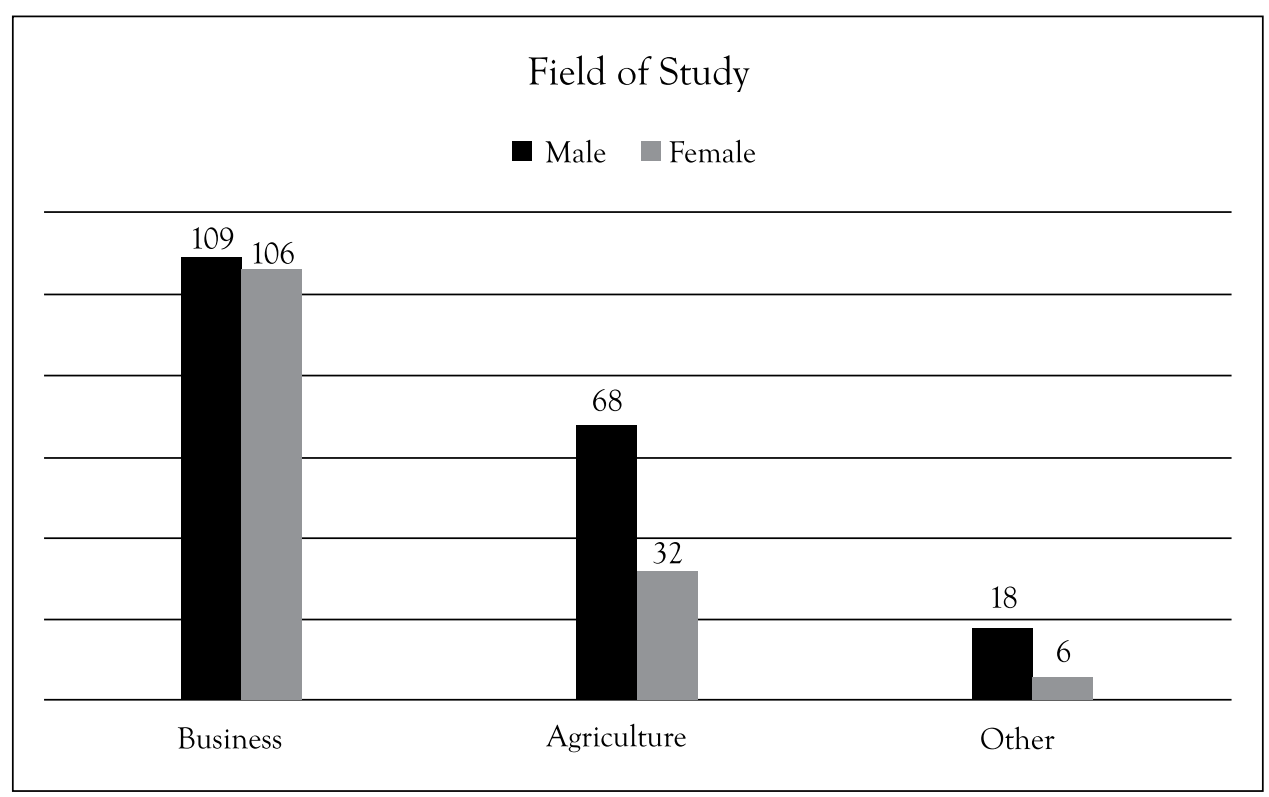

Figure 6: Field of Study Wise Frequency Distribution

Table 4 reveals that the ratio of business graduates was greater than that of agriculture students (63.5 percent and 29.5 percent respectively). More girls were in the business field than in agriculture (49 percent and 32 percent respectively). A small number of students from other departments also participated in this study. Lower participation from the agriculture students is because only one agriculture university participated in this study. These responses were collected through paying personal visits by researchers. A request through email was sent to the concerned persons of other three agriculture universities of Pakistan based at Sindh, Punjab and KPK but no any reply from those official emails received to date. It was not possible for researchers to visit those universities personally, therefore only responses of a single agriculture university are included in this study.

Table 5: Level of Studies Wise Frequency Distribution $(\mathrm{n}=339)$

\begin{tabular}{|c|c|c|c|c|}
\hline Education & Male & Female & Total & Percent \\
\hline Bachelor & 71 & 46 & 117 & 35 \\
\hline Master & 75 & 72 & 147 & 43 \\
\hline M.Phil / PhD & 49 & 26 & 75 & 22 \\
\hline Total & 195 & 144 & 339 & 100 \\
\hline
\end{tabular}

Source: Primary data based on this study 


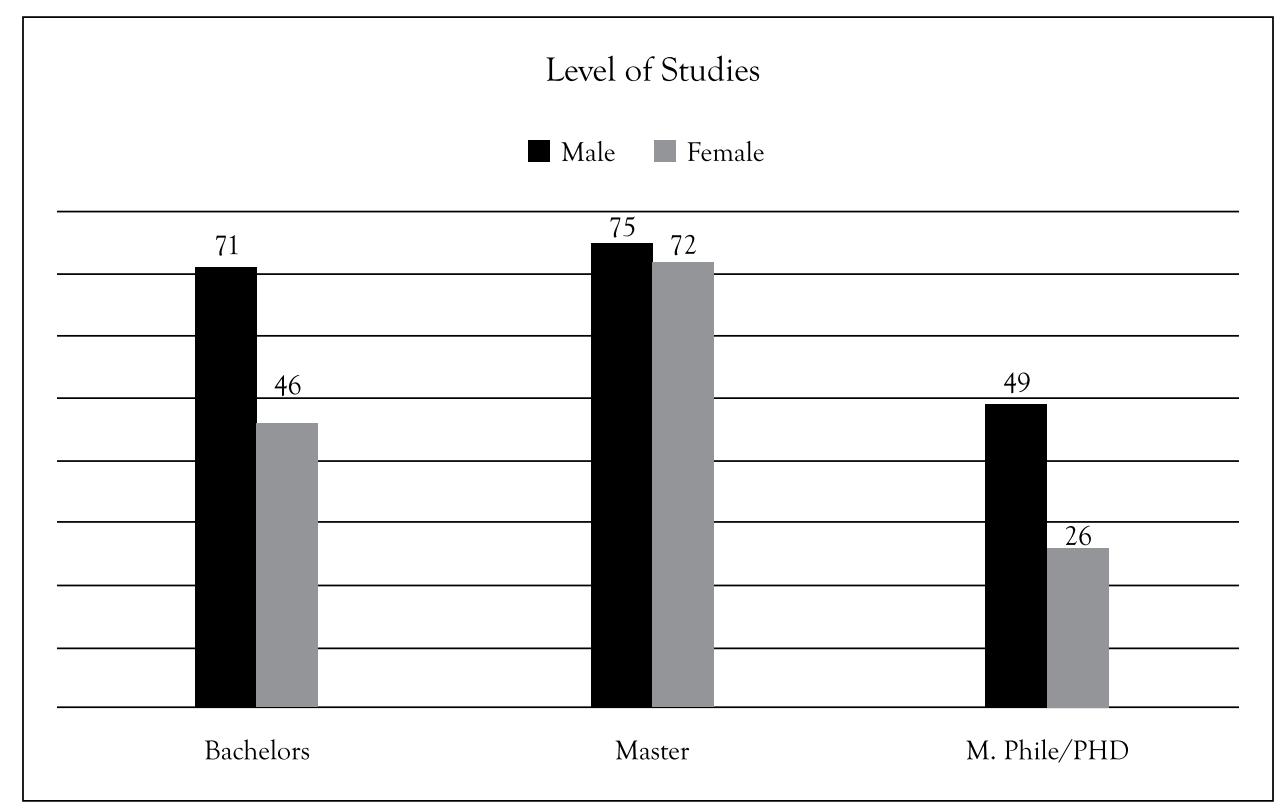

Figure 7: Level of Study Wise Frequency Distribution

Students were asked about the level of studies they were in. Responses reveal that more students who participated in the study were enrolled in the Master degree programs, that is, 16 years of education, whereas, students' enrollment in doctoral programs were 75 in which more boys (49) than girls (26) were enrolled. Number of bachelors students was 117 out of them there were 71 boys and 46 girls. Overall master degree students outnumbered where the ratio of girls and boys was almost equal.

Table 6: Experience Wise Frequency Distribution $(\mathrm{n}=339)$

\begin{tabular}{|c|c|c|c|c|c|c|c|}
\hline & \multicolumn{3}{|c|}{ Gender } & \multicolumn{3}{c|}{ University } & \multirow{2}{*}{ Total } \\
\cline { 2 - 7 } & Male & Female & Total & NDU & Arid & UoS & \\
\hline less than 1 year & 110 & 92 & 202 & 26 & 110 & 66 & 202 \\
\hline 2-5 year & 48 & 37 & 85 & 18 & 54 & 13 & 85 \\
\hline more than 5 years & 37 & 15 & 52 & 7 & 26 & 19 & 52 \\
\hline Total & 195 & 144 & 339 & 51 & 190 & 98 & 339 \\
\hline
\end{tabular}

Source: Primary data based on this study

Table 6 distributes sample in terms of any work experience they may have. It is evident that majority of students reported having no experience or less than one year work experience. Students who reported having experience of 2-5 year and more than five years were 85 and 52 respectively. More boys reported having any work experience than girls. 


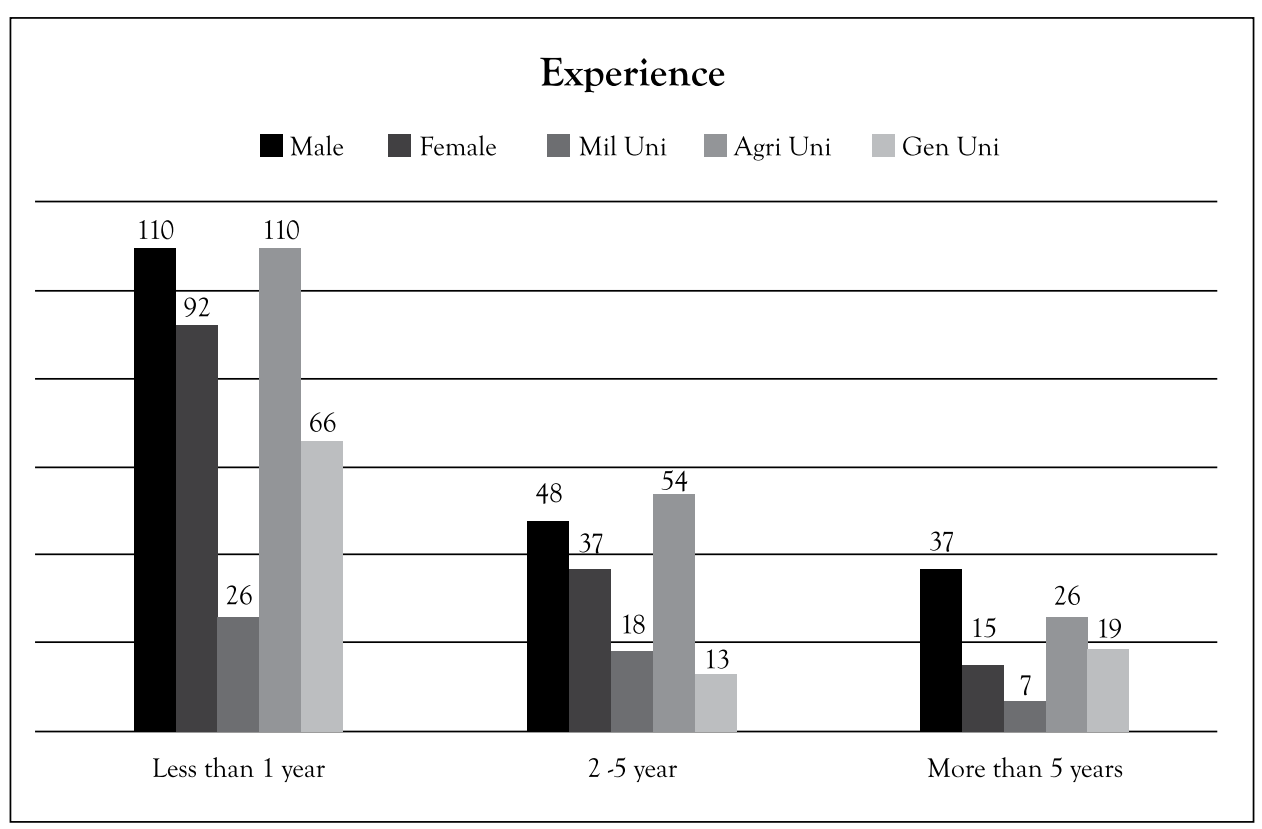

Note: Mil Uni = military university, Agri Uni = Agriculture University, Gen Uni = General University

Figure 8: Experience Wise Frequency Distribution

\subsection{Inferential statistics}

\subsubsection{Independent sample t-test}

As previous sections reported frequency of responses as to how many respondents agreed or disagreed with a particular item in the scale and what were the means and standard deviations. These descriptive statistics fail to report how individual identities in sample differ on these responses. Those identities might be gender, age, organization and so on. For the analysis of data of these individual groups, independent simple t-test and ANOVA are used. How respondents differ from each other and how much this difference is significant is the base for this analysis. In other ways, study variables are analyzed with regard to difference among demographic variables. Independent sample t-test is used to compare means between two unrelated groups, that is, Gender in this study.

Table 7 shows that there is no significant difference across the male and female respondents with regard to the psychological capital and self-perceived employability. Findings reveal that both the variables are equally important for both genders. 
Table 7: The Difference Among Study Variables with Regard to Gender ( $\mathrm{n}=339$ )

\begin{tabular}{|c|c|c|c|c|c|c|c|}
\hline Variable & Gender & $\mathrm{N}$ & Mean & $\begin{array}{l}\text { Std. Devia- } \\
\text { tion }\end{array}$ & $\begin{array}{l}\text { Std. Error } \\
\text { Mean }\end{array}$ & $\mathrm{F}$ & Sig. \\
\hline \multirow[t]{2}{*}{ Hope } & Male & 195 & 3.8564 & .98305 & .07040 & \multirow[t]{2}{*}{.064} & \multirow[t]{2}{*}{.800} \\
\hline & Female & 144 & 3.7257 & .71712 & .05976 & & \\
\hline \multirow[t]{2}{*}{ Optimism } & Male & 195 & 3.8564 & .73054 & .05231 & \multirow[t]{2}{*}{.008} & \multirow[t]{2}{*}{.930} \\
\hline & Female & 144 & 3.8310 & .72688 & .06057 & & \\
\hline \multirow{2}{*}{$\begin{array}{l}\text { Self-perceived } \\
\text { employability }\end{array}$} & Male & 195 & 3.6542 & .55737 & .03991 & \multirow[t]{2}{*}{3.044} & \multirow[t]{2}{*}{.082} \\
\hline & Female & 144 & 3.6450 & .46880 & .03907 & & \\
\hline \multirow[t]{2}{*}{ Self-Efficacy } & Male & 195 & 3.8709 & .58671 & .04201 & \multirow[t]{2}{*}{3.131} & \multirow[t]{2}{*}{.078} \\
\hline & Female & 144 & 3.8102 & .66684 & .05557 & & \\
\hline \multirow[t]{2}{*}{ Resilience } & Male & 195 & 3.8709 & .58671 & .04201 & \multirow[t]{2}{*}{3.131} & \multirow[t]{2}{*}{.078} \\
\hline & Female & 144 & 3.8102 & .66684 & .05557 & & \\
\hline
\end{tabular}

Source: Primary data based on this study

\subsection{ANOVA}

Independent sample $t$ - test discussed in the previous section fails to report when there are more than two options in the demographic variable. Gender had two groups, whereas, age, education, level of studies, filed of study, years of experience and type of university have more than two groups. Therefore, in such case ANOVA test is applied to compare means to test the differences with regard to these demographic variables.

Table 8 summarizes the results of the descriptive statistics, Test of Homogeneity of Variances and ANOVA which were applied to find the difference of significance level of self-perceived employability and PsyCap with respect to field of studies. The results indicate that mean score for business graduates $(\mathrm{M}=3.6541, \mathrm{SD}=.495, \mathrm{n}=$ $215)$ is slightly higher than that of the agriculture graduates $(\mathrm{M}=3.5719, \mathrm{SD}=.551$, $\mathrm{n}=100$ ), it means that the business graduates in comparison to agriculture graduates perceive themselves more employable than what agriculture graduates may perceive for themselves. Interestingly, mean score for other graduates $(\mathrm{M}=3.9427, \mathrm{SD}=.524$, $\mathrm{n}=24)$ is highest of all. This reveals that students of other departments surveyed in this study felt themselves more employable than the business and agriculture students. Before we go for ANOVA, results of the test of Homogeneity of Variance for self-perceived employability are analyzed. The results indicate that the $p$-value for Levine's test is greater than $0.05(\mathrm{p}=.271)$ and shows that the test of homogeneity is tenable. ANOVA table indicates that $\mathrm{F}$ and $\mathrm{p}$-value for self-perceived employability are $5.039(>3)$ and $.007(<0.05)$ respectively which indicate that there is a significant difference between groups of students based on their field of study with regard to 


\begin{tabular}{|c|c|c|c|c|c|c|c|c|c|c|c|c|c|}
\hline \multirow{2}{*}{$\begin{array}{l}\mathbb{Z} \\
0 \\
z \\
4\end{array}$} & $\ddot{\dot{0}}$ & \multicolumn{4}{|c|}{$\tilde{8}$} & \multicolumn{4}{|c|}{ ถ้ } & \multicolumn{4}{|c|}{ ถิ? } \\
\hline & $\omega$ & & م. & & & \multicolumn{4}{|c|}{$\overrightarrow{\vec{\sigma}}$} & \multicolumn{4}{|c|}{ กี } \\
\hline & $\stackrel{\dot{0}}{\dot{\infty}}$ & \multicolumn{4}{|c|}{ 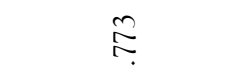 } & \multicolumn{4}{|c|}{$\stackrel{\circ}{m}$} & \multicolumn{4}{|c|}{ హె } \\
\hline $\begin{array}{l}\frac{\pi}{5} \\
\frac{5}{0}\end{array}$ & $\stackrel{t}{7}$ & \multicolumn{4}{|c|}{ లి } & \multicolumn{4}{|c|}{$\stackrel{m}{m}$} & \multicolumn{4}{|c|}{ లె } \\
\hline 焉 & $\exists$ & \multicolumn{4}{|c|}{$\sim$} & \multicolumn{4}{|c|}{$\sim$} & \multicolumn{4}{|c|}{$\sim$} \\
\hline 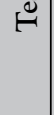 & 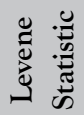 & \multicolumn{4}{|c|}{$\stackrel{\tilde{n}}{?}$} & \multicolumn{4}{|c|}{$\underset{ت}{\stackrel{ \pm}{\leftrightarrows}}$} & \multicolumn{4}{|c|}{ 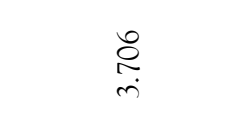 } \\
\hline \multirow{4}{*}{ 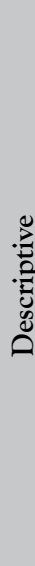 } & 岕 & $\begin{array}{l}0 \\
\text { t. } \\
t\end{array}$ & $\begin{array}{l}\text { fै } \\
\text { రి }\end{array}$ & 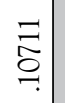 & 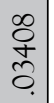 & $\begin{array}{l}\infty \\
0 \\
0 \\
0 \\
0 \\
0 .\end{array}$ & $\begin{array}{l}\tilde{2} \\
\frac{0}{\delta}\end{array}$ & \begin{tabular}{l}
0 \\
0 \\
0 \\
\hdashline \\
\end{tabular} & 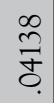 & $\begin{array}{l}\tilde{n} \\
\tilde{f} \\
0\end{array}$ & $\frac{0}{\sqrt{2}}$ & $\underset{\exists}{\stackrel{\sim}{\leftrightarrows}}$ & $\begin{array}{c}\underset{N}{\tilde{N}} \\
\tilde{0}\end{array}$ \\
\hline & की & $\begin{array}{l}2 \\
\underline{\sigma} \\
0 \\
0\end{array}$ & $\begin{array}{l}\text { ठे. } \\
\text { ఫै }\end{array}$ & 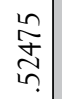 & 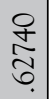 & $\begin{array}{l}0 \\
0 \\
\tilde{n} \\
\infty \\
\infty\end{array}$ & 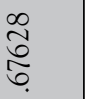 & $\begin{array}{l}0 \\
0 \\
0 \\
0 \\
0\end{array}$ & 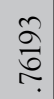 & 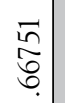 & 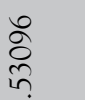 & 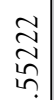 & $\begin{array}{l}\infty \\
\stackrel{\sqrt{t}}{\Xi} .\end{array}$ \\
\hline & 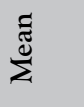 & 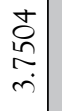 & $\begin{array}{l}8 \\
\infty \\
0 \\
\dot{n}\end{array}$ & 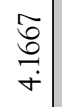 & $\begin{array}{l}\vec{\sigma} \\
\stackrel{n}{n} \\
m\end{array}$ & $\begin{array}{l}\vec{F} \\
\vec{\sigma} \\
\dot{m}\end{array}$ & 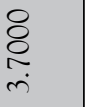 & 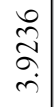 & $\begin{array}{l}n \\
0 \\
\infty \\
\infty \\
n \\
n\end{array}$ & 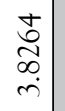 & $\begin{array}{l}\infty \\
\infty \\
\infty \\
\infty \\
\\
\end{array}$ & $\begin{array}{l}0 \\
2 \\
o \\
n \\
m\end{array}$ & $\begin{array}{l}\bar{z} \\
0 \\
0 \\
\dot{m}\end{array}$ \\
\hline & z & $\stackrel{n}{\sim}$ & 8 & $\stackrel{\sim}{\sim}$ & ले & $\stackrel{n}{\sim}$ & § & $\dot{\sim}$ & సે & $\stackrel{n}{\sim}$ & \& & $\stackrel{\Xi}{\sim}$ & ळे \\
\hline 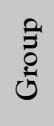 & & $\begin{array}{l}0 \\
0 \\
\stackrel{0}{0} \\
0 \\
0 \\
0\end{array}$ & 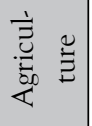 & 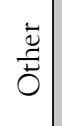 & 嵒 & 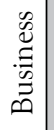 & 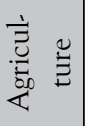 & $\begin{array}{l}\dot{\Xi} \\
\stackrel{ \pm}{0}\end{array}$ & 苞 & 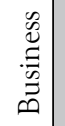 & 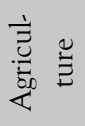 & $\begin{array}{l}\breve{\Xi} \\
\stackrel{\Xi}{0}\end{array}$ & 胥 \\
\hline 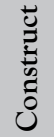 & & 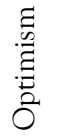 & & & & 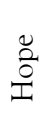 & & & & 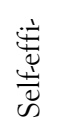 & & & \\
\hline
\end{tabular}




\begin{tabular}{|c|c|c|c|c|c|c|c|c|c|c|c|}
\hline \multicolumn{4}{|c|}{$\cong$} & \multicolumn{4}{|c|}{$\tilde{8}$} & \multicolumn{4}{|c|}{$\underset{\exists}{\tilde{J}}$} \\
\hline & $\begin{array}{l}\hat{\sigma} \\
\underset{\sim}{i}\end{array}$ & & & & ڤે & & & & $\stackrel{n}{\tilde{n}}$ & & \\
\hline \multicolumn{4}{|c|}{$\stackrel{\infty}{ \pm}$} & \multicolumn{4}{|c|}{$\underset{\sim}{ㄷ}$} & \multicolumn{4}{|c|}{$\stackrel{\sim}{n}$} \\
\hline \multicolumn{4}{|c|}{$\stackrel{\circ}{m}$} & \multicolumn{4}{|c|}{ 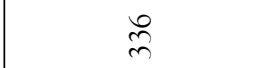 } & \multicolumn{4}{|c|}{ 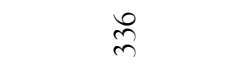 } \\
\hline \multicolumn{4}{|c|}{$\sim$} & \multicolumn{4}{|c|}{$\sim$} & \multicolumn{4}{|c|}{$\sim$} \\
\hline \multicolumn{4}{|c|}{$\stackrel{a}{\vec{\sigma}}$} & \multicolumn{4}{|c|}{ 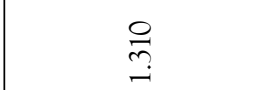 } & \multicolumn{4}{|c|}{ ?ৃర } \\
\hline 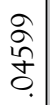 & 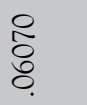 & $\begin{array}{c}\underset{D}{\mathbb{J}} \\
ٍ\end{array}$ & $\begin{array}{l}\infty \\
\tilde{N} \\
\tilde{0} \\
\hat{0}\end{array}$ & $\begin{array}{l}\infty \\
⿱ 亠 䒑 \\
\tilde{0} \\
.\end{array}$ & \begin{tabular}{l}
$\infty$ \\
\multirow{n}{n}{$\tilde{n}$} \\
0
\end{tabular} & $\begin{array}{l}\stackrel{2}{\Xi} \\
0 \\
-\end{array}$ & 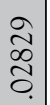 & 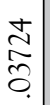 & 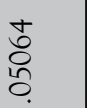 & \begin{tabular}{l}
\multirow{2}{n}{} \\
$\tilde{O}$ \\
\end{tabular} & $\begin{array}{c}\infty \\
\infty \\
\infty \\
\overparen{D} \\
0\end{array}$ \\
\hline 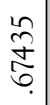 & $\begin{array}{l}\text { t } \\
\text { ठ } \\
\text { b. }\end{array}$ & 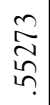 & $\begin{array}{l}\text { তु } \\
\text { ఫे } \\
0\end{array}$ & 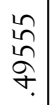 & $\begin{array}{l}\circ \\
\infty \\
i n \\
n\end{array}$ & 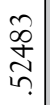 & 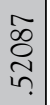 & $\begin{array}{l}\infty \\
o \\
o \\
+ \\
.\end{array}$ & 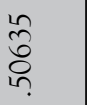 & 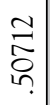 & $\begin{array}{l}n \\
\stackrel{n}{n} \\
\tilde{n} \\
\tilde{n}\end{array}$ \\
\hline $\begin{array}{l}\stackrel{0}{\sim} \\
\underset{\sim}{\sim} \\
\dot{m}\end{array}$ & $\begin{array}{l}\cong \\
\underset{0}{0} \\
\dot{m}\end{array}$ & $\begin{array}{l}\hat{\delta} \\
\delta \\
\dot{+}\end{array}$ & $\begin{array}{l}\tilde{n} \\
\stackrel{n}{*} \\
\dot{n}\end{array}$ & \begin{tabular}{l}
$\overrightarrow{7}$ \\
\multirow{2}{b}{} \\
$\dot{r}$
\end{tabular} & $\begin{array}{l}\underset{\curvearrowright}{\sim} \\
\stackrel{2}{n}\end{array}$ & \begin{tabular}{l}
$\tilde{y}$ \\
\multirow{J}{*}{} \\
$\dot{m}$
\end{tabular} & 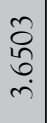 & $\begin{array}{l}\vec{\infty} \\
\infty \\
\infty \\
\dot{\sim}\end{array}$ & 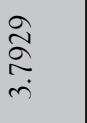 & $\begin{array}{l}\infty \\
\widetilde{\widetilde{V}} \\
\stackrel{+}{+}\end{array}$ & 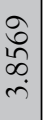 \\
\hline$\stackrel{n}{\sim}$ & \& & $\stackrel{\Xi}{\sim}$ & $\stackrel{m}{m}$ & $\stackrel{n}{\sim}$ & 8 & $\stackrel{\sim}{\sim}$ & ले & $\stackrel{n}{\sim}$ & \& & $\underset{\sim}{ \pm}$ & ๗ે \\
\hline 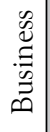 & 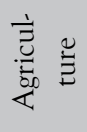 & 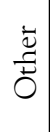 & 䒿 & 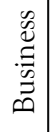 & 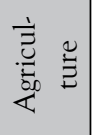 & 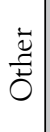 & 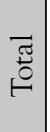 & 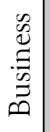 & 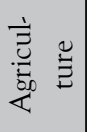 & 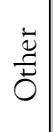 & $\stackrel{\widetilde{\varpi ే}}{\ominus}$ \\
\hline 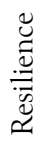 & & & & 嵌 & & & & 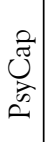 & & & \\
\hline
\end{tabular}


self-perceived employability.

Significance value less than 0.05 in ANOVA table indicates significant difference among groups of sample but fails to indicate exactly where the difference lies. This is done by post-hoc test such as Tukey honestly significant difference (HSD) test (Abdi \& Williams, 2010). In the column of mean difference mark of asterisk '*' indicates that the two groups being tested are statistically significantly different from each other at the level of 0.05 . For self-perceived employability table of multiple comparisons indicates that only other students are different from business and agriculture students on self-perceived employability. No difference was found between self-perceived employability of business and agriculture students.

For PsyCap, no significant difference was found among students of business administration, agriculture and others. Analysis of descriptive statistics reveals that the mean score for business graduates $(\mathrm{M}=3.8681, \mathrm{SD}=.546, \mathrm{n}=215)$ is slightly higher than that of the agriculture graduates $(M=3.7929, S D=.506, n=100)$, It means that business graduates in comparison to agriculture graduates are higher on PsyCap than what the agriculture graduates may perceive for themselves. Interestingly, the mean score for other graduates $(M=4.0238, S D=.504, n=24)$ is highest of all.

As regards dimensions of PsyCap, no difference was found among groups with regard to self - efficacy and resilience $(p>0.05)$, whereas, for hope $(p=0.056)$ and optimism ( $p=0.003$ ) there was significant difference among students of agriculture, business and others. Levene's test being insignificant also indicates that test of homogeneity is tenable. Table of multiple comparisons indicates that no difference was found between business and agriculture students on the level of optimism, whereas, significant difference was found between the two on the level of hope. Mean score of hope for business graduates $(\mathrm{M}=3.9171, \mathrm{SD}=.803, \mathrm{n}=215)$ is slightly higher than that of agriculture graduates $(\mathrm{M}=3.7000, \mathrm{SD}=.676, \mathrm{n}=100)$, It means that the business graduates in comparison to agriculture graduates are more hopeful than what the agriculture graduates may perceive for themselves. Interestingly, mean score for other graduates $(\mathrm{M}=3.9236, \mathrm{SD}=.640, \mathrm{n}=24)$ is highest of all. Almost the same situation lies in the mean score of optimism where business graduates are ahead of agriculture students with a higher mean score and score of other students remains greatest of the three.

Table 10 enlists values of means and standard deviations, test of homogeneity of variance and ANOVA for PsyCap. The table reveals that the students of master degree class bear overall highest mean score for self-efficacy $(\mathrm{M}=3.9512, \mathrm{SD}=.601$, $\mathrm{n}=147)$, resilience $(\mathrm{M}=3.8968, \mathrm{SD}=.583, \mathrm{n}=147)$, hope $(\mathrm{M}=3.9762, \mathrm{SD}=.646$, $\mathrm{n}=147)$, optimism $(\mathrm{M}=3.8787, \mathrm{SD}=.594, \mathrm{n}=147)$, self-perceived employability $(\mathrm{M}$ 
Table 9: Multiple Comparison with Regard to 'Field of Study' of Respondents

\begin{tabular}{|c|c|c|c|c|c|c|c|}
\hline \multirow{2}{*}{$\begin{array}{c}\text { Depen- } \\
\text { dent } \\
\text { Variable }\end{array}$} & \multirow[t]{2}{*}{ (I) Field } & \multirow[t]{2}{*}{ (J) Field } & \multirow{2}{*}{$\begin{array}{l}\text { Mean Dif- } \\
\text { ference } \\
(\mathrm{I}-\mathrm{J})\end{array}$} & \multirow[t]{2}{*}{ Std. Error } & \multirow[t]{2}{*}{ Sig. } & \multicolumn{2}{|c|}{$\begin{array}{c}\text { 95\% Confidence } \\
\text { Interval }\end{array}$} \\
\hline & & & & & & $\begin{array}{l}\text { Lower } \\
\text { Bound }\end{array}$ & $\begin{array}{l}\text { Upper } \\
\text { Bound }\end{array}$ \\
\hline \multirow[t]{6}{*}{ Optimism } & \multirow[t]{2}{*}{ Business } & $\begin{array}{l}\text { Agricul- } \\
\text { ture }\end{array}$ & .07039 & .07483 & .615 & -.1058 & .2466 \\
\hline & & Other & $-.41628^{*}$ & .13305 & .005 & -.7295 & -.1031 \\
\hline & \multirow{2}{*}{$\begin{array}{l}\text { Agricul- } \\
\text { ture }\end{array}$} & Business & -.07039 & .07483 & .615 &. .2466 & .1058 \\
\hline & & Other & $-.48667^{*}$ & .14052 & .002 & -.8175 & . 1559 \\
\hline & \multirow[t]{2}{*}{ Other } & Business & $.41628^{*}$ & .13305 & .005 & .1031 & .7295 \\
\hline & & $\begin{array}{l}\text { Agricul- } \\
\text { ture }\end{array}$ & $.48667^{*}$ & .14052 & .002 & .1559 & .8175 \\
\hline \multirow[t]{6}{*}{ Hope } & \multirow[t]{2}{*}{ Business } & $\begin{array}{l}\text { Agricul- } \\
\text { ture }\end{array}$ & $.21705^{*}$ & .09171 & .048 & .0012 & .4330 \\
\hline & & Other & .00656 & .16306 & .999 & -.3904 & .3773 \\
\hline & \multirow{2}{*}{$\begin{array}{l}\text { Agricul- } \\
\text { ture }\end{array}$} & Business &. $.21705^{*}$ & .09171 & .048 & -.4330 &. .0012 \\
\hline & & Other & -.22361 & .17222 & .397 & -.6290 & .1818 \\
\hline & \multirow[t]{2}{*}{ Other } & Business & .00656 & .16306 & .999 & -.3773 & .3904 \\
\hline & & $\begin{array}{l}\text { Agricul- } \\
\text { ture }\end{array}$ & .22361 & .17222 & .397 & -.1818 & .6290 \\
\hline \multirow[t]{6}{*}{ MEMP } & \multirow[t]{2}{*}{ Business } & $\begin{array}{l}\text { Agricul- } \\
\text { ture }\end{array}$ & .08219 & .06231 & .385 & .0645 & .2289 \\
\hline & & Other & $-.28864^{*}$ & .11078 & .026 & -.5494 & -.0278 \\
\hline & \multirow{2}{*}{$\begin{array}{l}\text { Agricul- } \\
\text { ture }\end{array}$} & Business & -.08219 & .06231 & .385 & -.2289 & .0645 \\
\hline & & Other & $-.37083^{*}$ & .11701 & .005 & -.6463 & -.0954 \\
\hline & \multirow[t]{2}{*}{ Other } & Business & $.28864^{*}$ & .11078 & .026 & .0278 & .5494 \\
\hline & & $\begin{array}{l}\text { Agricul- } \\
\text { ture }\end{array}$ & $.37083^{*}$ & .11701 & .005 & .0954 & .6463 \\
\hline
\end{tabular}

${ }^{*}$. The mean difference is significant at the 0.05 level.

Source: Primary data based on this study

$=3.7823, \mathrm{SD}=.491, \mathrm{n}=147)$ and overall PsyCap $(\mathrm{M}=3.9810, \mathrm{SD}=.477, \mathrm{n}=147)$. This shows that graduates of the master degree programs perceive themselves more hopeful, optimistic, efficient, resilient and employable than the graduates of bachelor and doctoral degree programs. This may be due to the fact that most of the jobs in Pakistan are preferentially offered to graduates of master degrees. Interestingly similar mean scores are reported for the graduates enrolled in bachelor and $\mathrm{PhD}$ degree pro- 


\begin{tabular}{|c|c|c|c|c|c|c|c|c|c|c|c|c|c|c|c|c|}
\hline & $\ddot{\infty}$ & \multicolumn{4}{|c|}{ ஜ̂. } & \multicolumn{4}{|c|}{$\tilde{8}$} & \multicolumn{3}{|c|}{$\stackrel{\circ}{\circ}$} & \multicolumn{4}{|c|}{ 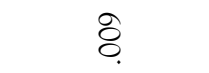 } \\
\hline \begin{tabular}{l}
\multicolumn{1}{c}{} \\
0 \\
$z$ \\
z
\end{tabular} & I & \multicolumn{4}{|c|}{$\frac{i n}{\stackrel{n}{n}}$} & \multicolumn{4}{|c|}{$\begin{array}{l}8 \\
\stackrel{\circ}{10}\end{array}$} & \multicolumn{3}{|c|}{$\underset{\vec{\sigma}}{\overrightarrow{+}}$} & \multicolumn{4}{|c|}{$\begin{array}{l}\text { I } \\
\infty \\
\dot{+}\end{array}$} \\
\hline & $\ddot{00}$ & \multicolumn{4}{|c|}{$\stackrel{\infty}{\stackrel{\sim}{*} .}$} & \multicolumn{4}{|c|}{ 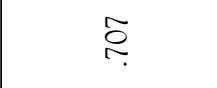 } & \multicolumn{3}{|c|}{$\overrightarrow{\tilde{n}}$} & \multicolumn{4}{|c|}{ ঃั } \\
\hline $\begin{array}{l}\overbrace{0}^{\pi} \\
\frac{\pi}{0} \\
.\end{array}$ & $\stackrel{\mathbb{v}}{0}$ & \multicolumn{4}{|c|}{$\underset{๗}{~}$} & \multicolumn{4}{|c|}{ లి } & \multicolumn{3}{|c|}{ లె } & \multicolumn{4}{|c|}{$\stackrel{\sim}{\infty}$} \\
\hline 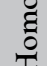 & $\Xi$ & \multicolumn{4}{|c|}{$N$} & \multicolumn{4}{|c|}{$\sim$} & \multicolumn{3}{|c|}{$\sim$} & \multicolumn{4}{|c|}{$\sim$} \\
\hline 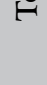 & 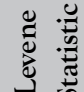 & \multicolumn{4}{|c|}{$\begin{array}{l}0 \\
\infty \\
\infty \\
\infty\end{array}$} & \multicolumn{4}{|c|}{ ‡్f } & \multicolumn{3}{|c|}{$\hat{n}$} & \multicolumn{4}{|c|}{ 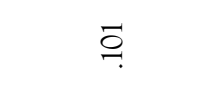 } \\
\hline & $\sqrt[n]{\infty}$ & 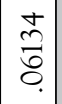 & $\begin{array}{l}n \\
0 \\
o \\
⿱ 亠 䒑 \\
0\end{array}$ & 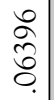 & $\begin{array}{l}\underset{N}{\tilde{n}} \\
\tilde{0} .\end{array}$ & 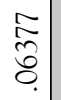 & $\begin{array}{c}\bar{F} \\
\overline{0} \\
0 \\
0\end{array}$ & $\begin{array}{l}n \\
0 \\
0 \\
\vdots \\
0\end{array}$ & $\begin{array}{l}0 \\
\tilde{W} \\
\tilde{n}\end{array}$ & $\begin{array}{c}\stackrel{\vartheta}{=} \\
\stackrel{0}{0}\end{array}$ & $\begin{array}{l}\hat{2} \\
\hat{n}\end{array}$ & 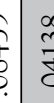 & $\begin{array}{l}\text { 웅 } \\
\text { bे } \\
\text { b. }\end{array}$ & $\begin{array}{l}\tilde{o} \\
\vdots \\
\dot{t} \\
0\end{array}$ & 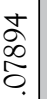 & $\begin{array}{l}\infty \\
0 \\
o \\
\text { ô. }\end{array}$ \\
\hline 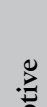 & के & 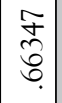 & 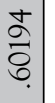 & $\begin{array}{l}\tilde{n} \\
\hat{\tilde{n}} \\
\text { กิ }\end{array}$ & 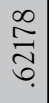 & $\begin{array}{l}0 \\
\stackrel{0}{2} \\
0 \\
0\end{array}$ & 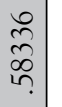 & $\begin{array}{l}\infty \\
0 \\
0 \\
0 \\
0\end{array}$ & 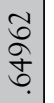 & $\begin{array}{c}\tilde{f} \\
⿱ \\
\infty \\
\infty \\
\infty\end{array}$ & $\begin{array}{l}0 \\
0 \\
0 \\
\vdots \\
0\end{array}$ & 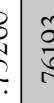 & $\begin{array}{l}\widetilde{\sigma} \\
\stackrel{8}{0}\end{array}$ & 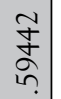 & 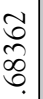 & $\underset{\substack{+ \\
\text { ț }}}{ }$ \\
\hline$\stackrel{\Xi}{ }$ & 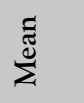 & $\begin{array}{l}\tilde{\hat{n}} \\
\stackrel{\rho}{n} \\
\dot{n}\end{array}$ & $\begin{array}{l}\frac{\pi}{n} \\
\dot{n} \\
\text { nat }\end{array}$ & $\begin{array}{l}\infty \\
i \\
i \\
\infty \\
\end{array}$ & $\begin{array}{c}\vec{n} \\
\bar{a} \\
\infty \\
\dot{m}\end{array}$ & 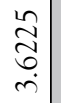 & $\begin{array}{c}\infty \\
0 \\
\infty \\
\infty \\
\dot{n}\end{array}$ & 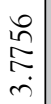 & 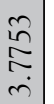 & $\begin{array}{c}\vec{v} \\
\vec{m} \\
\dot{\infty} \\
\dot{m}\end{array}$ & 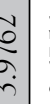 & 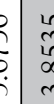 & 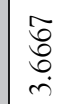 & $\begin{array}{c}\tilde{\infty} \\
0 \\
\infty \\
\tilde{m}\end{array}$ & 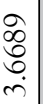 & 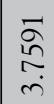 \\
\hline & $\mathrm{z}$ & $\Xi$ & 守 & $\stackrel{n}{\sim}$ & ๗े & $\Xi$ & 守 & 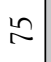 & ๗े & $\Xi$ & \pm & $\stackrel{\sim}{\tilde{N}}$ & $\Xi$ & 壬 & $\stackrel{n}{\sim}$ & ले \\
\hline 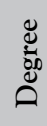 & & 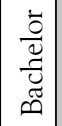 & 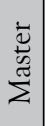 & $\stackrel{\theta}{a}$ & 急 & 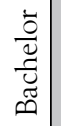 & 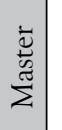 & $\frac{\theta}{a}$ & 焉 & 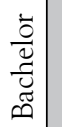 & $\begin{array}{l}\frac{\vec{z}}{\bar{z}} \\
\frac{\vec{z}}{2}\end{array}$ & 1 & 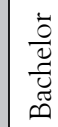 & $\begin{array}{l}\overrightarrow{\bar{u}} \\
\stackrel{5}{\tilde{z}}\end{array}$ & $\frac{\theta}{2}$ & 苟 \\
\hline $\begin{array}{l}\frac{0}{d} \\
\frac{\pi}{\pi} \\
\frac{\pi}{\pi}\end{array}$ & & $\begin{array}{l}\text { 离 } \\
\text { 离 } \\
\text { 心 }\end{array}$ & & & & 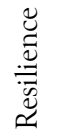 & & & & 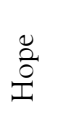 & & & 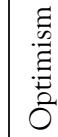 & & & \\
\hline
\end{tabular}




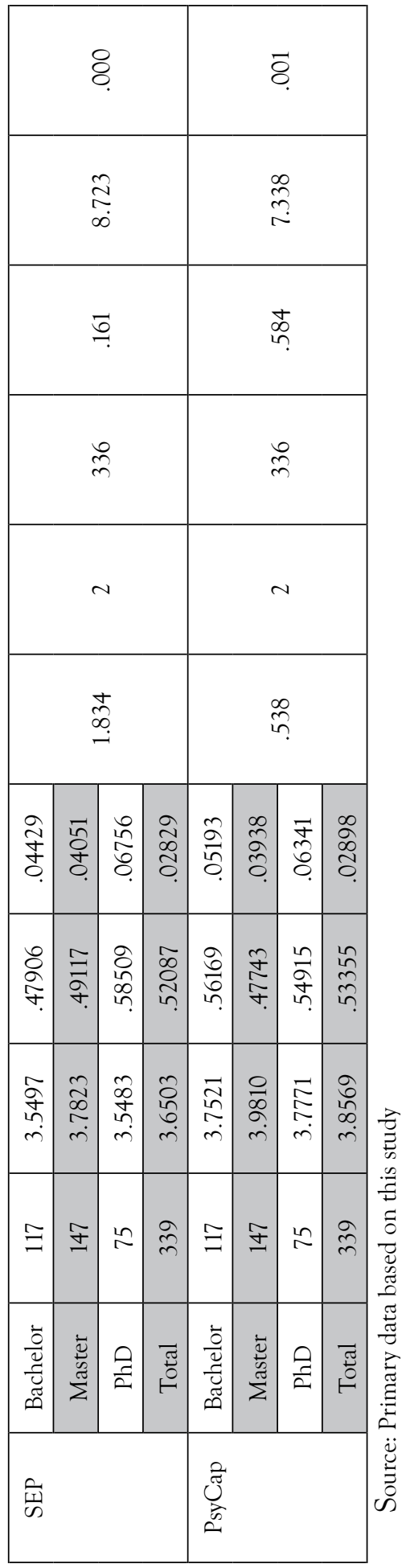


grams. Significance values of the test of homogeneity of variance for all variables are greater than 0.05 thus indicate that there is no violation of homogeneity of variance. Therefore, next we analyze the table of ANOVA which indicates that all the F values are greater than 3 and $p$ values are less than 0.05 . These statistics indicate that there is significant difference among groups of students based on their degree programs.

In order to locate the exact difference among groups we look at the table of multiple comparisons. Table 11 indicates that with regards to self-efficacy, resilience and optimism; the group of graduates of the master degree program $(\mathrm{M}=3.9512, \mathrm{M}=3.8968$ and $\mathrm{M}=3.8787$ respectively) is significantly different from the group of graduates of bachelor degree program $(\mathrm{M}=3.7037, \mathrm{M}=3.6225$ and $\mathrm{M}=3.6667$ respectively) with a mean difference of $.24754, .27432$ and .21202 respectively with a $p$ value of .004 , .002 and .017 respectively. The group of students of $\mathrm{PhD}$ degree programs was not found different from other two groups, that is, bachelor and master. For Hope, only difference is spotted between master and $\mathrm{PhD}$ groups $(\mathrm{M}=3.8134$ and $\mathrm{M}=3.6756$ respectively) with a mean difference of .30063 and $\mathrm{p}$ value .015 .

With regards to self-perceived employability, it is observed that the group of $\mathrm{PhD}$ graduates is not different from bachelors group, whereas the masters group is significantly different from the bachelors (Mean difference $=.23263 ; \mathrm{p}=.001$ ) and $\mathrm{PhD}$ (Mean difference $=.23398 ; \mathrm{p}=.004$ ) and for PsyCap too, no significant difference among $\mathrm{PhD}$ and bachelor groups was identified. The masters group is significantly different from the bachelors (Mean difference $=.22891 ; \mathrm{p}=.001$ ) and $\mathrm{PhD}$ (Mean difference $=.20391 ; \mathrm{p}=.018$ ).

Table 11: Multiple Comparison with Regards to 'Level of Studies' Of Respondents

\begin{tabular}{|c|c|c|c|c|c|c|c|}
\hline \multirow{2}{*}{$\begin{array}{c}\text { Depen- } \\
\text { dent } \\
\text { Variable }\end{array}$} & \multirow[t]{2}{*}{ (I) year } & \multirow[t]{2}{*}{ (J) year } & \multirow{2}{*}{$\begin{array}{l}\text { Mean Dif- } \\
\text { ference } \\
(\mathrm{I}-\mathrm{J})\end{array}$} & \multirow[t]{2}{*}{ Std. Error } & \multirow[t]{2}{*}{ Sig. } & \multicolumn{2}{|c|}{$\begin{array}{c}\text { 95\% Confidence } \\
\text { Interval } \\
\end{array}$} \\
\hline & & & & & & $\begin{array}{l}\text { Lower } \\
\text { Bound }\end{array}$ & $\begin{array}{l}\text { Upper } \\
\text { Bound }\end{array}$ \\
\hline \multirow{6}{*}{$\begin{array}{l}\text { Self-effi- } \\
\text { cacy }\end{array}$} & \multirow[t]{2}{*}{ Bachelor } & Master &. $.24754^{*}$ & .07607 & .004 & -.4266 & .0685 \\
\hline & & $\mathrm{PhD}$ & -15407 & .09082 & .208 & -.3679 & .0597 \\
\hline & \multirow[t]{2}{*}{ Master } & Bachelor & $.24754^{*}$ & .07607 & .004 & .0685 & .4266 \\
\hline & & $\mathrm{PhD}$ & .09347 & .08713 & .532 &. .1116 & .2986 \\
\hline & \multirow[t]{2}{*}{$\mathrm{PhD}$} & Bachelor & .15407 & .09082 & .208 & -.0597 & .3679 \\
\hline & & Master & -.09347 & .08713 & .532 & -.2986 & .1116 \\
\hline
\end{tabular}




\begin{tabular}{|c|c|c|c|c|c|c|c|}
\hline \multirow[t]{6}{*}{ Resilience } & \multirow[t]{2}{*}{ Bachelor } & Master & $-.27432^{*}$ & .07932 & .002 & -.4611 & -.0876 \\
\hline & & $\mathrm{PhD}$ & -15305 & .09471 & .240 & -.3760 & .0699 \\
\hline & \multirow[t]{2}{*}{ Master } & Bachelor & $.27432^{*}$ & .07932 & .002 & .0876 & .4611 \\
\hline & & $\mathrm{PhD}$ & .12127 & .09085 & .377 &. .0926 & .3352 \\
\hline & \multirow[t]{2}{*}{$\mathrm{PhD}$} & Bachelor & .15305 & .09471 & .240 & -.0699 & .3760 \\
\hline & & Master & -.12127 & .09085 & .377 & -.3352 & .0926 \\
\hline \multirow[t]{6}{*}{ Hope } & \multirow[t]{2}{*}{ Bachelor } & Master & -16280 & .09352 & .192 & -.3830 & .0574 \\
\hline & & $\mathrm{PhD}$ & .13783 & .11166 & .434 & -.1250 & .4007 \\
\hline & \multirow[t]{2}{*}{ Master } & Bachelor & .16280 & .09352 & .192 &. .0574 & .3830 \\
\hline & & $\mathrm{PhD}$ & $.30063^{*}$ & .10711 & .015 & .0485 & .5528 \\
\hline & \multirow[t]{2}{*}{$\mathrm{PhD}$} & Bachelor & .13783 & .11166 & .434 & -.4007 & .1250 \\
\hline & & Master & $-.30063^{*}$ & .10711 & .015 & -.5528 & -.0485 \\
\hline \multirow[t]{6}{*}{ Optimism } & \multirow[t]{2}{*}{ Bachelor } & Master & $-.21202^{*}$ & .07687 & .017 & -.3930 & -.0311 \\
\hline & & $\mathrm{PhD}$ & -.00222 & .09177 & 1.000 & -.2183 & .2138 \\
\hline & \multirow[t]{2}{*}{ Master } & Bachelor & $.21202^{*}$ & .07687 & .017 & .0311 & .3930 \\
\hline & & $\mathrm{PhD}$ & $.20980^{*}$ & .08804 & .047 & .0025 & .4171 \\
\hline & \multirow[t]{2}{*}{$\mathrm{PhD}$} & Bachelor & .00222 & .09177 & 1.000 & -.2138 & .2183 \\
\hline & & Master & $-.20980^{*}$ & .08804 & .047 & -.4171 & .0025 \\
\hline \multirow{6}{*}{$\begin{array}{l}\text { Self-per- } \\
\text { ceived } \\
\text { employ- } \\
\text { ability }\end{array}$} & \multirow[t]{2}{*}{ Bachelor } & Master & $-.23263^{*}$ & .06311 & .001 & -.3812 & -.0841 \\
\hline & & $\mathrm{PhD}$ & .00135 & .07535 & 1.000 & -.1760 & .1787 \\
\hline & \multirow[t]{2}{*}{ Master } & Bachelor & $.23263^{*}$ & .06311 & .001 & .0841 & .3812 \\
\hline & & $\mathrm{PhD}$ & $.23398^{*}$ & .07228 & .004 & .0638 & .4041 \\
\hline & \multirow[t]{2}{*}{$\mathrm{PhD}$} & Bachelor & -.00135 & .07535 & 1.000 & -.1787 & .1760 \\
\hline & & Master & $-.23398^{*}$ & .07228 & .004 & -.4041 & -.0638 \\
\hline \multirow[t]{6}{*}{ PsyCap } & \multirow[t]{2}{*}{ Bachelor } & Master & $-.22891^{*}$ & .06490 & .001 & -.3817 & -.0761 \\
\hline & & $\mathrm{PhD}$ & -.02501 & .07748 & .944 & -.2074 & .1574 \\
\hline & \multirow[t]{2}{*}{ Master } & Bachelor & $.22891^{*}$ & .06490 & .001 & .0761 & .3817 \\
\hline & & $\mathrm{PhD}$ & $.20391^{*}$ & .07433 & .018 & .0289 & .3789 \\
\hline & \multirow[t]{2}{*}{$\mathrm{PhD}$} & Bachelor & .02501 & .07748 & .944 & -.1574 & .2074 \\
\hline & & Master & $-.20391^{*}$ & .07433 & .018 & -.3789 & -.0289 \\
\hline
\end{tabular}

*. The mean difference is significant at the 0.05 level.

Source: Primary data based on this study 


\subsection{Hypothesis testing}

This section deals with testing of hypothesized paths though structural equation modeling (SEM) (Nizar \& Chagani, 2016). The conceptual framework is converted into a structural model in AMOS and hypotheses testing is carried out using path analysis.

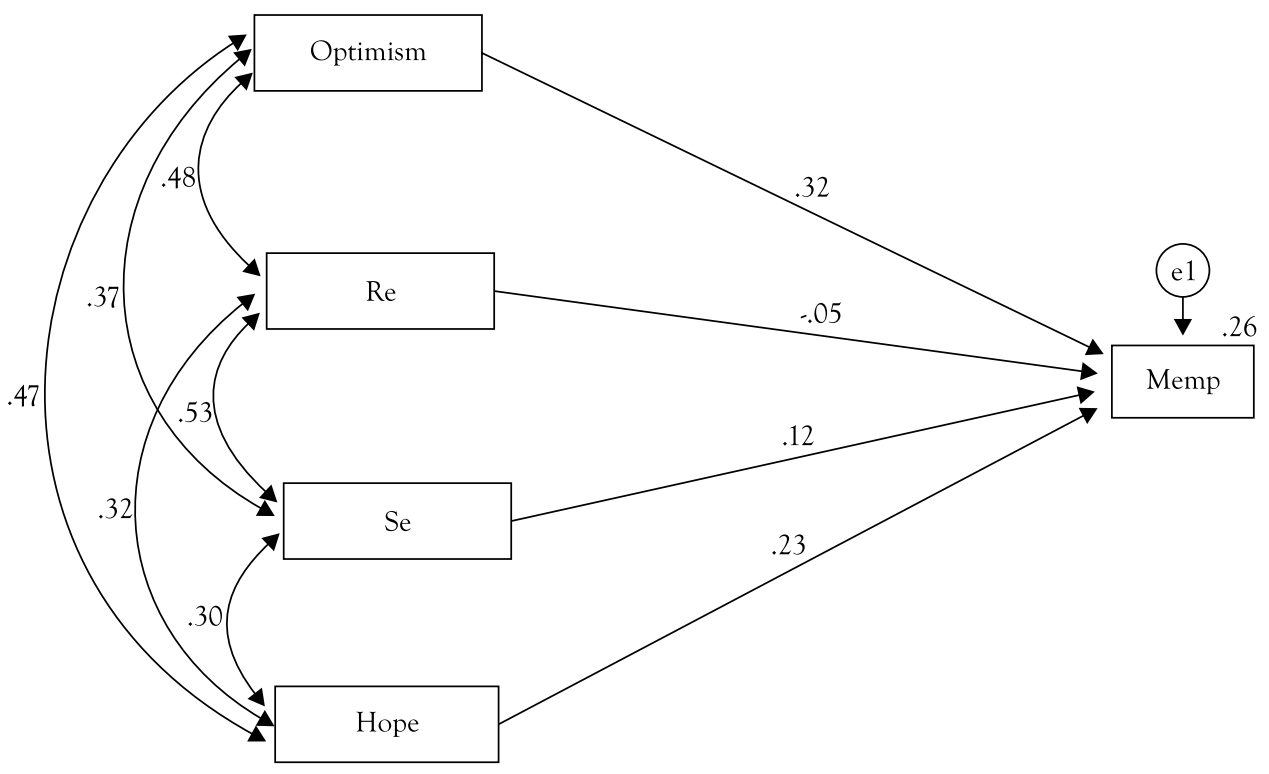

Figure 9: Direct Effects of PsyCap Dimensions on Self-Perceived Employability Note: RE = Resilience; SE = Self-efficacy; MEMP = Self-perceived employability

Hypothesis testing was carried through path analysis in AMOS 18.0. The first hypothesis was concerned about the impact of optimism on self-perceived employability. Results indicate that optimism is positively and significantly related to self-perceived employability $(\beta=.323 ; \mathrm{p}<.001)$ of graduates of this sample, thus hypothesis 1 is accepted. Hypothesis 2 was related to a positive relationship between resilience and self-perceived employability. The path between resilience and self-perceived employability was insignificant. Thus, hypothesis 2 is not accepted. The hypothesis 3 assumed positive relationship between self-efficacy and self-perceived employability. Results indicate that there is positive and significant relationship between self-efficacy and self-perceived employability $(\beta=.117 ; \mathrm{p}<.05)$. hypothesis 3 assumed positive a relationship between hope and self-perceived employability. Results confirm the hypothesis $(\beta=.235 ; \mathrm{p}<.001)$. In sum, three out of four hypotheses are supported.

\section{Discussion}

This study formulated a model to test the impact of psychological capital on the graduates of business and agriculture. The first section of this study is related 
Table 12: Regression Estimates of PsyCap Dimensions on Self-perceived Employability.

\begin{tabular}{|c|c|c|c|c|c|}
\hline Variables & & & Estimate & P-Value & $\begin{array}{c}\text { Hypothesis } \\
\text { Support }\end{array}$ \\
\hline $\begin{array}{c}\text { Self-perceived } \\
\text { employability }\end{array}$ & $<-$ & Optimism & .323 & $* * *$ & H1 supported \\
\hline $\begin{array}{c}\text { Self-perceived } \\
\text { employability }\end{array}$ & $<-$ & Resilience & -.046 & .442 & $\begin{array}{c}\text { H2 Not sup- } \\
\text { ported }\end{array}$ \\
\hline $\begin{array}{c}\text { Self-perceived } \\
\text { employability }\end{array}$ & $<-$ & Self-efficacy & .117 & .038 & H3 supported \\
\hline $\begin{array}{l}\text { Self-perceived } \\
\text { employability }\end{array}$ & $<$ & Hope & .235 & $* * *$ & H4 supported \\
\hline
\end{tabular}

Source: Primary data based on this study

to the comparison of graduates of business, agriculture and others with regard to self-perceived employability and psychological capital. Results indicate that there was a significant difference between business and agriculture students only on the hope dimension of PsyCap. No significant difference was found between business and agriculture students' PsyCap and Self-Perceived Employability. Results also indicate that some other students $(n=24)$ included in this study who belonged to international relations department, government and public policy, English literature and information technology were found significantly different from business and agriculture students with regards to self-perceived employability and PsyCap.

Second section was related to test hypotheses concerning the impact of PsyCap on self-perceived employability. Results indicate that optimism, self-efficacy and hope are positively and significantly related to self-perceived employability. Luthans et al. (2016) in their study of 323 business graduates of two Midwestern universities found positive link of academic PsyCap with students' engagement with their studies. Authors also argued that the PsyCap may be important predictor of other student related constructs such as self-perceived employability. This study fills this gap by incorporating responses of 339 business and agriculture students of various level from bachelor to $\mathrm{PhD}$ to test the impact of PsyCap on employability of perception of graduates. Datu, King, and Valdez (2016) found PsyCap relevant to academic setting. In their causal and longitudinal studies they found positive link of PsyCap with autonomous motivation, academic achievement and engagement. Authors also suggested that as there is dearth of studies with regard to test impact of PsyCap in academic outcomes therefore, there is need of empirical studies to fill this gap. Another study from Srilankan Universities found positive impact of Psycap with change related outcomes such as affective and normative commitment to change (Naotunna, 2015). This study may 
be a significant addition to the body of knowledge by providing empirical evidence of testing impact of PsyCap on self-perceived employability of graduates from three universities of Pakistan.

\subsection{Theoretical and practical implications}

The conversation of resources theory posits that psychological resources are important indicators of work tasks as well as perceptions and behaviours (Hobfoll, 1989). Psychological capital has received greater attention in the literature and has been tested as predictor of behaviours and perceptions. Although no study found that may have tested PsyCap with self-perceived employability; evidence is present that it is related to variety of employee attitudes, behaviours and performance (Avey et al., 2011). Hogan, Chamorro-Premuzic, and Kaiser (2013) proposed a model of psychological determinants of employability through a literature review. Authors argue that cognitive abilities and personality factors such as ambition may serve as an important predictor of career success. This study adds to this stream of research by suggesting that psychological capital may form a greater resource which when coupled with other social resources will be an important indicator of graduate employability (Hobfoll, 1989; Hsu \& Chen, 2017).

The important implication of this study for theory and practice is that the policy makers of higher education institutions must take into account the development of student psychological resources like psychological capital so that they perceive themselves as important contributor to the economy and labour market.

\subsection{Limitation and future recommendation}

This study is not exempted from possible limitations. Major limitation to this study is its causal design which may preclude the determination of causal effects. This study also lacks important possible mediators between the link of PsyCap and employability such as students' academic performance. Therefore, there is need to test this model in a longitudinal study by incorporating some important mediators and moderators.

Important future avenue for research in graduate employability may be to undertake a longitudinal study. It will be pertinent to inquire whether graduates' perception of employability actually contributes to their employment on completion of the degree? ${ }^{1}$ This study proposes a longitudinal study which may record students' perceptions before they join the University, during their study programs and tracking their employment progress after the completion of degree. Research suggests that graduate employability perceptions coupled with career management skills have an economic impact (Bridgstock, 2009, p. 38). A review of 40 studies investigating economic benefits 
of students' guidance revealed that graduates' selection of suitable courses, retention of those courses and learning outcome may translate economic benefits in terms of decreased time for searching new jobs, decrease in unemployment, improvement in productivity and reduced turnover (Hughes, Bosley, Bowes, \& Bysshe, 2002).

\section{Conclusion}

The role of psychological resources in the development of organizationally and personally relevant outcomes is well-thought. This study contributes in the literature by identifying the equal importance of PsyCap and self-perceived employability for the business and agriculture students as well as this study has found positive link of the dimensions of PsyCap with self-perceived employability This study may serve as a first step toward the development of model of psychological determinants of graduate employability.

\section{References}

Abdi, H., \& Williams, L. J. (2010). Tukey's honestly significant difference (HSD) test. In Encyclopedia of research design. (pp. 1-5). Thousand Oaks, CA: Sage.

Avey, J. B., Reichard, R. J., Luthans, F., \& Mhatre, K. H. (2011). Meta-analysis of the impact of positive psychological capital on employee attitudes, behaviors, and performance. Human Resource Development Quarterly, 22(2), 127-152.

Bakari, H., Hunjra, A. I., \& Niazi, G. S. K. (2017). How does authentic leadership influence planned organizational change? The role of employees' perceptions: Integration of theory of planned behavior and Lewin's three step model. Journal of Change Management, 17(2), 155-187. doi:10.1080/ 14697017.2017.1299370

Bakari, H., Hunjra, A. I., \& Saman, A. (2017). Measuring access to higher education: Development and validation of scale. Pakistan Business Review, 19(3), 706-722.

Bandura, A. (1986). Social foundations of thought and action: A social cognitive theory. Englewood Cliffs, NJ: Prentice-Hall, Inc.

Bowden, J., Hart, G., King, B., Trigwell, K., \& Watts, O. (2000). Generic capabilities of ATN university graduates. Retrieved from Canberra: https://goo.gl/ZCwrXP

Bridgstock, R. (2009). The graduate attributes we've overlooked: Enhancing graduate employability through career management skills. Higher Education Research $\mathcal{E}$ Development, 28(1), 31-44. doi: $10.1080 / 07294360802444347$

Datu, J. A. D., King, R. B., \& Valdez, J. P. M. (2016). Psychological capital bolsters motivation, engagement, and achievement: Cross-sectional and longitudinal studies. The Journal of Positive Psychology, 1-11. doi:10.1080/17439760.2016.1257056 
Dawkins, S., Martin, A., Scott, J., \& Sanderson, K. (2013). Building on the positives: A psychometric review and critical analysis of the construct of psychological capital. Journal of Occupational and Organizational Psychology, 86(3), 348-370.

Fibel, B., \& Hale, W. D. (1978). The generalized expectancy for success scale: A new measure. Journal of Consulting and Clinical Psychology, 46(5), 924.

Hobfoll, S. E. (1989). Conservation of resources: A new attempt at conceptualizing stress. American Psychologist, 44(3), 513.

Hogan, R., Chamorro-Premuzic, T., \& Kaiser, R. B. (2013). Employability and career success: Bridging the gap between theory and reality. Industrial and Organizational Psychology, 6(1), 3-16. doi:10.1111/ iops.12001

Hsu, M. L. A., \& Chen, F. H. (2017). The cross-level mediating effect of psychological capital on the organizational innovation climate-employee innovative behavior relationship. The Journal of Creative Behavior, 51(2), 128-139. doi:10.1002/jocb.90

Hughes, D., Bosley, S., Bowes, L., \& Bysshe, S. (2002). The economic benefits of guidance. Derby: Centre for Guidance Studies, University of Derby.

Luthans, B. C., Luthans, K. W., \& Jensen, S. M. (2012). The impact of business school students' psychological capital on academic performance. Journal of Education for Business, 87(5), 253-259.

Luthans, F. (2002). The need for and meaning of positive organizational behavior. Journal of Organizational Behavior, 23(6), 695-706. doi:10.1002/job.165

Luthans, F., Avolio, B. J., Avey, J. B., \& Norman, S. M. (2007). Positive psychological capital: Measurement and relationship with performance and satisfaction. Personnel Psychology, 60(3), 541-572.

Luthans, F., Youssef, C. M., \& Avolio, B. J. (2015). Introduction to the meaning of and need for psychological capital. In Psychological capital and beyond (pp. 1-18). Oxford: Oxford University Press.

Luthans, K. W., Luthans, B. C., \& Palmer, N. F. (2016). A positive approach to management education: The relationship between academic PsyCap and student engagement. Journal of Management Development, 35(9), 1098-1118.

Martin, A. J., Milne-Home, J., Barrett, J., Spalding, E., \& Jones, G. (2000). Graduate satisfaction with university and perceived employment preparation. Journal of Education and Work, 13(2), 199-213.

Naotunna, S. (2015). Psychological capital a positive approach to enhance commitment to change among university students. American Journal of Educational Research, 3(6), 765-769. doi:10.12691/ education-3-6-16

Pool, L. D. (2017). Developing graduate employability: The CareerEDGE model and the importance of emotional intelligence. In M. Tomlinson \& L. Holmes (Eds.), Graduate Employability in Context: Theory, Research and Debate (pp. 317-338). London: Palgrave Macmillan UK. 
Pool, L. D., \& Qualter, P. (2013). Emotional self-efficacy, graduate employability, and career satisfaction: Testing the associations. Australian Journal of Psychology, 65(4), 214-223.

Pool, L. D., \& Sewell, P. (2007). The key to employability: Developing a practical model of graduate employability. Education + Training, 49(4), 277-289. doi:doi:10.1108/00400910710754435

Qenani, E., MacDougall, N., \& Sexton, C. (2014). An empirical study of self-perceived employability: Improving the prospects for student employment success in an uncertain environment. Active Learning in Higher Education, 15(3), 199-213.

Riolli, L., Savicki, V., \& Richards, J. (2012). Psychological capital as a buffer to student stress. Psychology, 3(12), 1202.

Rothwell, A., Herbert, I., \& Rothwell, F. (2008). Self-perceived employability: Construction and initial validation of a scale for university students. Journal of Vocational Behavior, 73(1), 1-12.

Samo, A. H., \& Mahar, A. H. (2016). GUESSS: Report for Pakistan. Sukkur Institute of Business Administration, Sindh

Scheier, M. F., \& Carver, C. S. (1985). Optimism, coping, and health: Assessment and implications of generalized outcome expectancies. Health psychology, 4(3), 219.

Seligman, M. P. E. (1998). Learned optimism. New York, NY: Pocket Books.

Sieger, P., Fueglistaller, U., \& Zellweger, T. (2016). Student entrepreneurship 2016: Insights from 50 countries. International GUESSS report, St.Gallen/Bern: KMU-HSG/IMU.

Snyder, C. R., Irving, L. M., \& Anderson, J. R. (1991). Hope and health. In C. R. Snyder \& D. R. Forsyth (Eds.), Handbook of social and clinical psychology: The health perspective (pp. 285-305). Elmsford, NY: Pergamon.

Stajkovic, A. D., \& Luthans, F. (1998). Self-efficacy and work-related performance: A meta-analysis. Psychological bulletin, 124(2), 240-261.

Yorke, M. (2006). Employability in higher education: What it is-what it is not. York, England: The Higher Education Academy.

Youssef, C. M., \& Luthans, F. (2012). Psychological capital: Meaning, findings and future directions. In G. M. Spreitzer \& K. S. Cameron (Eds.), The oxford handbook of positive organizational scholarship (pp. 17-27). Oxford, UK: Oxford University Press.

Zarafshani, K., Knobloch, N. A., \& Aghahi, H. (2008). General perceived self-efficacy of Iranian College of Agriculture students. Journal of International Agricultural and extension education, 15(1), 69-84. 
